\title{
Political Studies of Multiculturalism; Approach Citizenship Education Towards Strengthening Nationalism of the People of Papua
}

\author{
$1^{\text {st }}$ Harun Gafur ${ }^{1}$ \\ \{harungafur2@gmail.com\} \\ Universitas Pendidikan Muhammadiyah Sorong, West Papua, Indonesia
}

\begin{abstract}
The politics of multiculturalism is a challenge for the development of the implementation of education which is a vehicle for the achievement of the competencies of citizens. The potential for conflict in multicultural societies is quite large, the phenomenon of conflict is young citizens who are far from the impact of human resource development and others. One effort that can be taken to strengthen nationalism is through education. The purpose of this article is to formulate Citizenship Education in the study of the politics of multiculturalism studies to strengthen the nationalism of the people as Indonesian citizens in the land of Papua. The writing method used is library research and the study of research results on strengthening nationalism through citizenship education and the study of political multiculturalism. The results of this discussion are to direct the younger generation as citizens who have competence "Act locally and think globally". Competencies that can preserve and maintain the values, culture, and customs of Indonesian citizens, but have a global perspective following the development of the international world that will not forget the value of nationalism related to national independence and unity.
\end{abstract}

Keywords: Politics, Multiculturalism, Nationalism, Papua Community

\section{Introduction}

Indonesia is a unitary state that starts from community ties between groups of people in the form of a nation in the homeland which is geographically located in an archipelago consisting of several islands with a variety of languages, tribes, races, and cultures. The historical fact of the development of the Indonesian nation as an archipelago was established on December 13, 1957 by Indonesian Prime Minister Djuanda Kartawidjaja through a declaration named exactly as its originator, the Djuanda Declaration (Darmaputra, 2009: 12). As a consequence of the territorial centrality as an archipelago, Indonesia has several border areas on land (continents) and sea borders (maritime). Indonesia's natural and cultural riches are not inferior to the number of islands. These characteristics differ, both geographically, socio-culturally, and ethnicity, race, and religion make Indonesia the largest multicultural country in the world (Zarbaliyev, 2016). If this is not realized as a gift from God, it can also be a trigger for conflicts between tribes, races, groups, and even religions on each island because of its differences. There is a dark note at the end of the Suharto regime (Budiman, 2010). Therefore, it is necessary to strengthen the sense of love and pride as an Indonesian nation in 
order to strengthen unity and integrity. An understanding of loving and maintaining the Unitary Republic of Indonesia is called nationalism.

Nationalism in Papua is very important to maintain the unity and integrity of the Republic of Indonesia. Papua region is a location that is very vulnerable to the fading feelings and attitudes of nationalism. This is due to the location of the region that is very far from the center of government or can be said to be the area closest to neighboring countries. On the other hand, globalization also affects the degradation of nationalism due to high mobility in interacting with citizens who have different citizenship. The impact, not a few phenomena that affect the use of multilingual languages, multiple currencies, the consumption of products from other countries has an impact on the sense of pride towards one's own country (Dedes, 2015: 2). It is here, the importance of fostering and strengthening a sense of nationalism through multicultural studies in the Papuan community which is not impossible to erode nationalism due to closeness both geographically, socio-culturally, and interaction with other citizens. Young citizens are becoming one of the serious concerns about the effects of nationalism degradation in the Papua land area. Young citizens in the land of Papua is a national asset that will continue the fate of the nation and the state going forward. One way that can be taken in fostering nationalism in young citizens through education. Education is an important factor in strengthening the character of the Indonesian people, especially in the younger generation in Papua.

From the approach of school education, it has an obligation to maintain and strengthen the nationalism values of its students in order to realize sustainable development in the context of strengthening nationalism in schooling. Based on Article 1 Number 2 of Law Number 20 Year 2003 concerning the National Education System which reads "National Education is education based on the Pancasila and the 1945 Constitution of the Republic of Indonesia which is rooted in religious values, the national culture of Indonesia, and responsive against the demands of the times ". Schooling education specifically has a great responsibility in fostering nationalism of young citizens. Subjects that have the aim of forming good and smart citizens based on Indonesian quality are Pancasila Education and Citizenship. The main components taught in Citizenship Education to students include civic knowledge, civic skills, and civic disposition. This component becomes the main indicator in strengthening the nationalism of young citizens, especially in the land area of Papua. Based on nationalism data, Citizenship Education in multicultural studies needs to be reformulated which intensively strengthens the nationalism of young citizens in the land of Papua. This paper tries to provide a new picture of the approach of Citizenship Education in multicultural studies to foster, instill, and strengthen the nationalism of young citizens in the land of Papua.

\section{Research Methods}

The method of writing this article uses the library research method. This method is used to answer preliminary studies (prelinmary research) to understand more deeply the new symptoms that are developing in the field or in society (Zed, 2004). Furthermore, according to Zed (2004: 54), explaining that library research is a series of activities regarding methods of collecting library data, reading and recording and processing research materials. 


\section{Time and Place of Research}

The process of preparing this article starts from the assumption based on the data in accordance with the topic of discussion. Based on these assumptions, a follow-up is then carried out by grouping data systematically to provide an explanation of these assumptions. After that, the data that has been collected is systematically analyzed and interpreted to explain phenomena with a scientific thought line. Thus, it will create an initial solution to address the issues raised in this article.

\section{Research Target/Subject}

Some of the main types of literature used consist of books and journal articles on Citizenship Education, Politics, Multiculturalism, Nationalism, Communities in the land of Papua and laws on national education.

\section{Procedure}

The research began with data collection conducted with a literacy study, which identified various references related to the article title. Data or information, obtained from the literature that can be accounted for. Furthermore, compiled based on the results of studies from various literatures that have relatively different grace periods, so that they are related to each other and in accordance with the themes discussed.

\section{Data Collection Instruments and Techniques}

The data used comes from journal articles and other scientific literature that are textual based on the thematic essence related to each other stated by the expert or the expert has a correlation with the discussion. More data sources than data collection, namely personal documents in the form of research articles that have been published from online and offline. Online data is in the form of research articles, while offline data comes from primary books and regulations relating to the topic of this article. Data collection techniques using documentation techniques, coding data from books, journals, and related literature that has a correlation with this article. After that, it will be translated back into transcripts, notes, and so on to obtain validity of the data.

\section{Data Analysis Techniques}

Data analysis is carried out inductively, which consists of two stages, namely the process of data reduction and data presentation. Data reduction aims to make it easier for authors to choose valid data, while presenting data so that it is possible to draw conclusions. Withdrawal of conclusions obtained after referring to the purpose of writing, analysis and synthesis. 
Conclusions also pay attention to the presentation of data from the discussion that was drawn to represent the main points in the paper and supported with practical advice as further recommendations. Withdrawal of conclusions obtained after referring to the formulation of the problem, the purpose of writing, analysis and synthesis. Conclusions also pay attention to the presentation of data from the discussion that was drawn to represent the main points in the paper and supported by practical advice as further recommendations.

\section{Results and Discussion}

\subsection{Citizenship Context}

The term citizenship comes from the word civic which means citizenship. Then it was developed by the ICCE TEAM (Indonesia Center for Civic Education) (2005) under the term Citizenship Education. Max A. Hope (2012: 98) explains that good citizenship education needs to develop knowledge and skills, and values in three interrelated fields including social responsibility, morals, community involvement and political literacy. Citizenship education plays an important role in building and supporting responsible citizenship in any country (Sutiyono, Suharno 2018: 06-09).

With the power of thought, the broader spirit of nationalism of citizens is also narrowed back by the spirit of partyism, tribalism, koncoisme, fundamentalism and regionalism. In such a situation, the project of nationalism of young citizens initiated at the time of the youth oath goes backwards. The rare retreat of our Indonesianness as a nation that does not embody the role of citizenship is very apparent from the cracks that are taking place and that we face today. In the independence movement, the boundary between us has expanded its horizons by linking various differences into the national and Indonesian fantasies. But in the development of the unitary state of the Republic of Indonesia today, the boundary between us continues to shrink, divided by the fantasy of "kelianan" (otherness).

The crisis of Pancasila values in the identity of public citizens reflects the neglect of the world of education and culture in developing "Civic intelligence Quotient". Our education places too much emphasis on individual intelligence, with no regard for efforts to link the diversity of individual intelligence into collective-citizenship intelligence. Each person is allowed to be a series of "letters" of the alphabet, without being arranged as a whole in differences (unity in diversity) into "words" and "sentences" together. As a result, many good and intelligent human beings do not become citizens and state administrators who are good and smart do not become citizens and state administrators who are good and smart (aware of their obligations and rights). In fact, the Indonesian nation as a multi-structured society requires consensus regarding the basis of values and collective direction as an expression of shared identity and will. Therefore, civic education based on Pancasila in the multicultural dimension of Snagat is needed.

The development of "civic intelligence" is more fundamental for a nation that wants to free itself from the colonization of individualism that drives capitalism and colonialism. The basic postulate of individualism believes that social relations are not the formation of individuals in their most fundamental experience. Social relations are indeed something that happens to individuals but are not seen as something that defines identity and coordinates the existence of individuals. The very famous phrase from individualism states: "You come into the world alone, and leave the world alone." Despite the fact that no one is born into the world alone. There is always a mother and community culture that accompanies it, even taking her to 
the "final resting place" (Yudi Latif, 2016: 05).

Citizenship in the study of social theory that each human person cannot stand alone except for the existence of the other. Every person forms and forms a network of social relations. All human beings, except those who live under extraordinary circumstances, depend on forms of collaboration and collaboration with others that enable humans to develop their human potential in securing basic material conditions to continue their lives and progeny. The development of the identity of citizens does not only provide a vehicle for each individual to recognize who he is as a "special manifestation" of nature. The development of identity must also provide a vehicle for everyone to recognize and develop culture as a system of values, knowledge systems, and systems of shared behavior that are crystallized against the values of Pancasila. Pancasila as a value system is certainly able to provide a stimulus to human behavior as a whole in social environmental activities that can determine whether the disposition of individual characters that develops for the better or worse.

So from the development of these values, the "citizenship intelligence" based on Pancasila is the key to integrating the values and progress of the nation. However, it is precisely at that point that the weakest node of the current education and development process.

\subsection{The Politics of Multiculturalism and Character Education}

The true diversity of Indonesian society, becomes a driver for the robust development of human resources in Papua. Multiculturalism is often perceived as the politics of teaching and the value of diversity in a plural society. Various concepts relevant to multiculturalism include, among others, democracy. Justice and law, cultural values and ethos, togetherness in equal differences, ethnicity, ethnic culture, religious beliefs, cultural expressions, private and public domains, human rights, community cultural rights, and other relevant concepts. Thus in the midst of the diversity turmoil, national character development appears not necessarily, but comprehensively influences and impacts on the formation of civic responsibility.

Etymologically multiculturalism was used in the 1950s in Canada. According to Longer Oxford Dictionary the term "multiculturalism" is a deviation from the word "multicultural". The direction or goal of multiculturalism politics is: "recognition of cultural diversity that fosters awareness so that various marginalized groups can be integrated, and society accommodates cultural differences so that the distinctiveness of their identities is recognized". While the goals of multiculturalism politics are: forming tolerance, openness, and facilitating consensus. Offsetting technocratic economic policies, multiculturalism proposes a new system of representation and participation. Public spatial planning involves three aspects, namely physical-social, cultural, and political. (Anita Trisiana, 2016: 548)

The potential for conflict in multicultural societies is quite large, due to the low index of human resource development that causes loss of character values both citizens in Papua and throughout the archipelago, it is difficult for the nation and state to continue to face challenges, various conflicts born from reality the diversity. In this case, education is an important solution to shape the character of a multicultural society. If we look at past history, exemplary character bases are given by the nation's founders and other national figures.

Now the example is a rare commodity. The elite, for the most part, are no longer providing role models for the community. They are more concerned with each other's interests and do not think about efforts to progress progress. As an example that has been given previous national figures. The character that has been initiated by the founder of this nation is a character that is in accordance with the values of Pancasila, namely Nation and Character Building and is part of strengthening civic responsibility. (Anita Trisiana, 2016: 543), Multicultural issues then increasingly crystallized in a more extreme view, namely 
multiculturalism. With the addition of "ism" and the root word (multicultural), this term is apparently increasingly not easily understood. According to, Bethany Bryson (Anita Trisiana, 2016: 548), a University of Virginia professor, tried to trace the complexity of the meaning of the word. He interviewed a number of caliber professors in multicultural affairs who finally came to the conclusion that the meaning of the term was still vague and needed to be fought for.

In a theoretical context, learning from multicultural education models that have existed and applied so that being developed by developed countries, is known in five approaches, namely: first, education about cultural differences or what is called multiculturalism. Second, education recognizes cultural differences or cultural understanding. Third, education for cultural pluralism. Fourth, bi-cultural education. Fifth, multicultural education as a basis and practice of human morals.

The politics of multiculturalism is a challenge for the development of the implementation of national character education which is a vehicle for the achievement of the competencies of citizens. Character education is very important and there are no other choices for realizing a new Indonesia, namely Indonesia that can face contemporary challenges as global citizens. The politics of multiculturalism is carried out to be a supporter of the implementation of character education, namely through the concept of multicultural education in a society that is full of problems between groups which poses significant challenges. Multicultural education does not mean merely "celebrating diversity". Especially if there is still a society that is full of discrimination and racism. In such conditions multicultural education is better directed as a basis for advocacy to create a tolerant society.

In a basic study according to Anita Trisiana (2016: 553), the development of character education in the midst of diverse societies, various challenges arise in building civic responsibility, in the political perspective of multiculturalism, among others, that: 1). Society is a living, dynamic and always developing existence. 2). Society depends on the efforts of each individual to meet their needs through relationships with other individuals who work together to meet their needs, structuring those efforts in the way of so-called social challenges. 4). Every community is responsible for forming behavioral patterns between individuals and communities that make up society. 5). The growth of individuals in the community, their attachment to them, and their development within a frame that leads them to take responsibility for their behavior.

\subsection{Study of Papua Community Nationalism}

Nationalism originates from the Nation derived from the Latin nation, which was developed from the word nascor (I was born) meant as a group of people who were born in the same area (Sutarjo Alisusilo, 04). According to the big Indonesian dictionary (2010: 997) nationalism is the understanding (teachings) to love the nation and the state itself politically to defend the self-government of nationality. In Indonesia nationalism is a symbol of the State, nationalism is a pillar for the nation. Nationalism has a simple meaning that is the mental attitude and behavior of individuals or society that shows the existence of loyalty or high devotion to the nation and state. One of the inculcation and strengthening of nationalism values is through the development of human resources through education. Improving the quality of education in the border areas especially in Papua needs to get extra serious attention from various parties. Because an increase in resources will have a major impact on improving the welfare of the community. Education is the main foundation to build the nation's future, so education is a major factor of a person's quality. Therefore, the 1945 Constitution also regulates the importance of education in accordance with Article 31 paragraph 1, namely that 
every citizen has the right to receive education. The process of implementing the mandate of the law is education through the school channel. The connection with the inculcation of the values of nationalism subjects that can be used as a vehicle to instill nationalism is citizenship education is expected to realize good citizenship. Burton and May (2015: 76) argued through citizenship education being able to shape good behavior of citizens and be able to compete in the global era.

One of the negative impacts of globalization is that the influence of culture and lifestyle on the development of globalization can affect nationalism. Nationalism is not only a lesson in the cognitive domain but must also develop in the effective and psychomotor domains. Nationalism in the border regions and in Papua is still lacking, this was revealed by Fariastuti Djafar, $(2015: 1)$ that the government's lack of attention, poor infrastructure and far from other regions in Indonesia made it easier for them to sell agricultural products, such as areca nut and others to meet their daily needs and needs.

In addition to the problem of social inequality, community awareness in the border regions and Papua region is still lacking in nationalism. Nationalism is considered merely knowledge and not as a basis for action in social life so that with the problem of nationalism various questions arise, namely how the development of education exists in enhancing the nationalism of Papuan citizens. Renan, Hutchinson and Smith, (Sutiyono, Suharno 2018: 0607): defines that "a nation is a soul, a spiritual principle .... a grand solidarity". The term "nation" is basically one soul, a spiritual principle, a considerable solidarity. Everything has been shaped by awareness about living together. This can be channeled with historical narratives about past glories or sufferings. Then, the glory narrative is expected to bring up a sense of pride. Meanwhile, the narrative of past suffering is expected to be able to evoke a "willingness to sacrifice". This is where the great moral basis of solidarity manifests.

The study of "nation" is shown differently by Joseph Stalin in Budiawan, 2017 (Sutiyono, Suharno 2018: 06), defines "nation" as "a hostorically constitude, stable community of people, formed on the basis of a common language, territory, economic life, and psychological make-up manifested in a common culture "(Hutchinson and Smith, 1994: 18-19). "Nation" is a stable community, formed historically on the basis of the similarity of language, territory, economic life, and psychological character as manifested in a shared culture. Stalin even emphasized that only when all of these features are present together, that is where a "nation" is formed. Stalin, more see a similarity in terms of outward not including the inner.

This means that ethnic/cultural/linguistic similarity is not necessarily the basis of the formation of a "nation", on the contrary, ethnic/cultural/linguistic differences do not always hinder the formation of a "nation." Thus, Rogers Brubaker (Sutiyono, Suharno, 2018: 09-10): said that Weber's thinking about "nation" and "nationalism" that "nation" was not the concept of "a category of analysis", but "a category of practice". Because, nattionhood is basically not ethnodemographic or ethnocultural facts, but political claims. More precisely is the claim for the loyalty of people with care, attention and solidarity. As stated by Anthonny Giddens (1985: 38) defines that the "nation" is only possible if the "state" has a unified administrative or governmental coverage of the territory claimed to be its sovereign territory. Gidden believes that the nation-state is a set of institutional forms of governance, namely government, territory, and sovereignty. Then most of the "nation" and "state" are often used interchangeably and both are considered to be relatively the same. Connor tried to explain the emergence of "nation" and "state" which began with the French Revolution, when there was a transformation from L'etat c'est moi (the state is me / king) to L'etat c'est le peuple (the state is the people). With this incident, the "state" is required to embody or become a servant of the 
public interest. Starting from here the concept of "nation" and "state" is almost the same. In this context, the term nationalism emerged as an ideology that demanded people's loyalty to the "nation", easily deviated from being loyal to the "state". Today, fascism and totalitarianism are emerging, which is an extreme form of nationalism, which demands total loyalty of every individual or citizen to the "state", which is nothing but a ruling regime. It also cannot be separated from the identical terms between "nation" and "state". The emergence of fascism and totalitarianism, making "state" is no longer a bodyguard, but rather a hostage of the concept of "nation". Unfortunately, the process of taking hostage "nation" is carried out democratically, so that it is like "legitimate". Based on the merger of the two, "nation-state", an ideology that supports and supports it is called nationalism.

\subsection{Approach to Citizenship Education and Nationalism of the Papua People}

The era of globalization in the dimension of modernity is now easily and very quickly influencing human culture, including the lives of people in the land of Papua, both among the younger generation and the older generation. Moreover, the influence of globalization, modernization at the level of information technology at this time is very vulnerable to the decline in nationalism. Robertson (Rini Ismanan, 2016: 384) argues that the process of globalization is considered as a process that frees every State or individual to be able to show their abilities because the world no longer has borders and there are no obstacles to express freedom. So people with the view that globalization tends to have the opportunity to obtain various things in everyday life. Another opinion according to Drezner, (Rini Ismanan, 2016: 384) globalization and nationalism can be mixed, where globalization and nationalism can promote each other. In addition to modernity, this is a challenge for the younger generation as well as an opportunity base in strengthening the nationalism of young citizens in Papua.

From the approach and description of the arguments analyzed in defacto, of course, requires logical study as an instrument of value. In another approach Elie Kedourie (Sutiyono, Suharno 2018: 09) said that nationalism is a comprehensive doctrine and guides and directs people towards a particular country model (a unique political style). This is based on the view that humans are autonomous (self-determination) beings who have the choice to determine their own history. Therefore, this concept gives birth to what is called patriotism and xenophobia. Patriotism is a form of loyalty to the state, group, or institution that supports it. Meanwhile, xenophobia is a dislike of strangers or outside the group. So, this nationalism gave birth to two new concepts namely inward faced sentiment and outward faced sentiment. Methods of kedoure thinking, such as Hegelian, were opposed by Ernest Gellner (Sutiyono, Suharno 2018: 11). Gellner discusses that history is not formed from a thought or idea, but rather what is shaped by history or at least the idea itself is never autonomous. Gellner believes that historically the idea of a "nation" is a phenomenon of "modernization". This concept of modernization accelerates the multiplication of results rather than history. The idea of nationalism originated from elitism to be populist, then nationalism claimed that nationalism claimed that nationalism was rooted in popular culture. When viewed from this perspective, nationalism is rooted in popular culture. When viewed from this perspective, nationalism is like self-deception.

The concept of approaches and arguments to strengthen nationalism empirically is very important to produce philosophical values. Quoting what Paul R Brass wrote (Sutiyono, Suharno, 2018: 06). He tried to reconcile the primordialist and instrumentalist approaches. The result, according to Paul R Brass, nationalism is a product of contestation between elite groups in a society. Each elite group tries to choose certain aspects of the group culture. Only selected cultural aspects can be considered to unite all elements in the group and be useful for the 
benefit of the group.

The need for a State to continue to maintain the attitude of nationalism of its citizens, because the existence of an attitude of nationalism will unite the differences that exist in a country as stated by Synder (Vinta Larasati, 2016: 59) That nationalism is related to national independence and unity. Strengthening the nationalism of young Papuan citizens towards a unitary state of the Republic of Indonesia that needs to be done to foster attitudes and behaviors that reflect national values, namely: students feel happy and proud to be Indonesian citizens, students are able to appreciate the services of heroes who have fought for Indonesian independence, students have a sense of helping and helping others, loving domestic products, visiting friends who are sick, respecting teachers and teachers at school, respecting friends, not forcing compactors to others, Trisandi (Vinta Larasati, 2016: 60). Papuans are geographically located as a unitary state of the Republic of Indonesia with the Pancasila ideology, but over time, Pancasila is no longer considered the basis of the State. There are also community behaviors that no longer reflect attitudes based on Pancasila. Culture from the outside seems more interesting to emulate, used as a guide in behavior. Ideology from outside can enter and influence society and replace the value of Pancasila, because it considers that Pancasila is no longer relevant to the age of globalization.

The most important thing to foster and strengthen the sense of nationalism of the people and young Papuan citizens is through civic education with the concept of multiculturalism so that good citizens will naturally be formed. The learning approach at school must also be collaborated with the value of local wisdom, which later is useful to foster an attitude of nationalism of young citizens, not education that is indoctrinated in order to follow and believe what the government says, but rather to jasmine the analysis attitude of students as young citizens towards the country's problems not only criticism but also being solutive and how to grow the critical attitude of young citizens in facing the negative impacts of the globalization era and being able to make the best use of this globalization era. Citizenship education in a good multicultural concept is one that is capable of developing knowledge, skills, and not forgetting values in three interrelated fields, namely: social, moral, and spiritual responsibility and involvement in politics.

\section{Conclusions and Suggestions}

\subsection{Conclusion}

The Citizenship Education Approach is intended to direct students or young people to have a competency called "Acting locally and thinking globally". Competencies that can preserve and maintain the values, culture, and customs of Indonesia, but have a global perspective following the development of the international world that will not forget the values of nationalism related to independence and national unity. Strengthening the nationalism of young Papua citizens towards a unitary state of the Republic of Indonesia that needs to be done to foster attitudes and behaviors that reflect national values, namely: students as young citizens feel happy and proud to be Indonesian citizens, students are able to appreciate the services of the heroes who have fighting for Indonesian independence, students having a sense of helping others, loving domestic products, visiting friends who are sick, respecting fathers and mothers at school, respecting friends, not appreciating imposing coagulation on others, Papuans in geographical locations as a unitary state Republic of Indonesia whose ideology is Pancasila. 
The most important thing to foster and strengthen the sense of nationalism of the community and young people is through citizenship education with the concept of multiculturalism so that good citizens will be formed naturally. Can not be separated from young citizens such as people in the border region of Papua must understand, realize, make demands of conscience must love and act real in maintaining and developing an identity based on Indonesian values namely Pancasila, the 1945 Constitution, the Republic of Indonesia, and Unity in Diversity. Thus, through the Citizenship Education approach is expected to encourage the strengthening of nationalism of young citizens in the border region.

\subsection{Suggestion}

Nationalism of young citizens in Papua including the border region is very important to strengthen the unity and integrity of the Unitary Republic of Indonesia. Citizenship Education must be directed towards the contents of a holistic understanding of the importance of maintaining the values of local wisdom in accordance with Pancasila without ignoring the development of technology and information while at the same time directing students to have a global perspective to be able to compete in the national and international arena.

\section{Reference}

[1] Anderson, B.: Imagined Communities: Reflections on the Origin and Spread of Nationalism. hlm.6. London, Verso (1999)

[2] Anita Trisiana.: Proseding konfrensi nasional kewarganegaraan ke-2 "penguatan kajian atas isu-isu actual kewarganegaraan dalam konteks kependidikan dan non-kependidikan. hlm. 543-553. Yogyakarta: Lab. PKn FIS UNY. (2016

[3] Gidden, A.: The Nation-State and Violence. hlm. 38. Berkeley \& Los Angeles: University of California Press. (1985)

[4] Hutchinson, J. \& Smith, A. D.: Nationalism. hlm. 18-19. Ixfoerd \& New York: Oxford University Press. (1994).

[5] Keith, Burton., \& Shane, O.: After nation? Critical Reflection on Nationalism and Postnationalism. Palgrave Macmilan: New York. (2015)

[6] Kerr, D.: Citizenship: Local, National, and International. Hlm.15-16 The Taylor \& Francis e-Library. (1999)

[7] Lee. W. O., \& Grossman, D. L. (Eds).: Citizenship Education In Asia And The Pasific Concepts And Issuse. Hongkong: The Unisersity of Hong Kong Pokfulam. (2004)

[8] Maftuh dan Sapriya.: Implementasi KBK Pendidikan Kewarganegaraan dalam Berbagai Konteks. hlm. 319-328. Jurnal Civicus. (2005)

[9] Max A. H.: Becoming citizens through school experience: A case study of democracy in practice. Vol.8 No.3: 94-108. International Journal pf Progressive Education. (2012)

[10] Moses, C.: Civic Education and Global Citizenship: A Deweyan Perspective. No. 6 (1). 1-25. Journal of Peace Education and Social Justice. (2012)

[11] Sidoarjo. Kajian Moral dan Kewarganegaraan, 1 (1) Peraturan Pemerintah Nomor 12 Tahun 2010 tentang Badan Nasional Pengelola Perbatasan (BNPP).

[12] Poetranto T.: Strategi Penanganan Wilayah Perbatasan. hlm. 4-6. Buletin Puslitbang Strahan Balitbang Dephan. (2008)

[13] Rini Ismanan.: Proseding konfrensi nasional kewarganegaraan ke-2 "penguatan kajian atas isu-isu actual kewarganegaraan dalam konteks kependidikan dan non-kependidikan. Yogyakarta: Lab. PKn FIS UNY. (2016)

[14] Sutiyono, Suharno.: Citizenship Jurnal Pancasila dan Kewarganegaraan Vol 6 No 1 April, hal 116 Avaliable online at : http://e journal.unipma.ac.id/index.php/citizenship ISSN: 2302-433X (print) 2579-5740 (online). (2018)

[15] Undang-undang Nomor 43 Tahun 2008 Tim ICCE UIN. Demokrasi, Hak tentang Wilayah Negara Asasi Manusia, Masyarakat Madani (Edisi Revisi). Jakarta: Prenada 
Media. (2003)

[16] Vinta Larasati.: Proseding konfrensi nasional kewarganegaraan ke-2 "penguatan kajian atas isu-isu actual kewarganegaraan dalam konteks kependidikan dan non-kependidikan. Yogyakarta: Lab. PKn FIS UNY. (2016)

[17] Yudi Latif.: Proseding konfrensi nasional kewarganegaraan ke-2 "penguatan kajian atas isu-isu actual kewarganegaraan dalam konteks kependidikan dan non-kependidikan. Yogyakarta: Lab. PKn FIS UNY. (2016)

[18] Zed, M.: Metode Penelitian Semarang, Semarang Kepustakaan. Jakarta: PT Raja Grafindo Persada. (2004) 